\title{
Unieke gedragsfenotipes in die hertmuismodel (deer mouse model) van obsessiewe-kompulsiewe siekte en die reaksie daarvan op serotonergiese en dopamienergiese geneesmiddelbehandeling
}

\section{Outeurs: \\ Arina Fick, \\ BH Harvey, \\ D Wolmarans ${ }^{a}$ \\ Affiliasies: \\ asentrum van Uitnemend- \\ heid vir Farmaseutiese \\ Wetenskappe, Fakulteit \\ Gesondheidswetenskappe, \\ Noordwes-Universiteit \\ Privaatsak X6001, \\ Potchefstroom, 2520 \\ ${ }^{b} M N R$-Eenheid vir Risiko en \\ Weerstand in Geestesver- \\ steurings, Potchefstroom}

Korresponderende outeur: D Wolmarans

E-pos:

dewet.wolmarans@nwu.ac.za

Hoe om hierdie artikel aan te haal:

Arina Fick, BH Harvey,

D Wolmarans, Unieke

gedragsfenotipes in die

hertmuismodel (deer

mouse model) van

obsessiewe-kompulsiewe

siekte en die reaksie

daarvan op serotonergiese

en dopamienergiese

geneesmiddelbehandeling,

Suid-Afrikaanse Tydskrif

vir Natuurwetenskap en

Tegnologie 38(1) (2019).

https://doi.org/10.36303/

SATNT.2019.38.1.768

\section{Kopiereg:}

(C) 2019. Authors.

Licensee: Die Suid-

Afrikaanse Akademie vir

Wetenskap en Kuns.

Hierdie werk is onder

die Creative Commons

Attribution License

gelisensieer.

\begin{abstract}
Unique behavioural phenotypes in the deer mouse model of obsessive-compulsive disorder $(O C D)$ and its response to serotonergic and dopaminergic drug treatment: This study hypothesised that large nest building and high marble-burying in deer mice could be representative of different OCD phenotypes, for example, safety/perfectionism and hoarding OCD respectively. We further investigated whether high marble-burying may be representative of a treatment-resistant OCD phenotype that may be responsive to unique dopaminergic drug intervention.
\end{abstract}

Slegs 40 tot $60 \%$ van pasiënte met obsessiewe-kompulsiewe siekte (OKS) reageer voldoende op eerstelinie-selektiewe serotonienheropnameremmers (SSHRs). Wat egter selfs belangriker is, is dat slegs sowat die helfte van SSHR-weerstandige pasiënte wat vervolgens aanvullende behandeling ontvang, positief daarop reageer. Onlangse sielkundige navorsing wat ondersoek ingestel het na hoe pasiënte met verskillende OK-simptoomtipes belonings- en strafverwante uitkomste verwerk, het getoon dat OK-pasiënte wat veral aan versamelingskompulsies ly, swak vaar met betrekking tot beloningsgeörienteerde gedrag, terwyl dié wat aan sekuriteits- en perfeksionisme-verwante kompulsies ly, swak vaar ten opsigte van straf-geörienteerde gedrag. Neurologies beskou, word beweer dat die twee neuro-oordragstowwe, dopamien (DA) en serotonien (5HT), teenstrydige dog balanserende rolle speel in die verwerking van beloningsen strafverwante terugvoer. Meer spesifiek word geglo dat DA beloningsgerigte gedrag sal versterk en aanmoedig, terwyl 5HT strafverwante gedrag sal voorkom. Omdat hierdie prosesse uniek wanfunksioneel is in pasiënte met verskillende OK-simptoomtipes, kan die vraag gevra word of verskillende OK-simptome op hoogs-selektiewe serotonergiese en dopamienergiese geneesmiddelbehandeling sal reageer wat daarop gerig is om hierdie unieke verskille aan te spreek. Hierdie projek het daarom ten doel om twee verskillende gedragsfenotipes in die hertmuismodel, naamlik abnormaal groot nesbougedrag (GNB) en hoë albasterbegrawegedrag (HAB), waarvan die laasgenoemde geen reaksie op SSHRs toon nie, te gebruik om hierdie vraag te beantwoord. Ons stel voor dat GNB, wat in 30\% van die hertmuispopulasie voorkom en as ' $n$ voorstelling van veiligheids- en perfeksionistiese obsessies aangevoer word, op slegs 'n SSRH of gekombineerd met 'n DA-antagonis sal reageer, terwyl HAB, wat slegs in $11 \%$ van die hertmuispopulasie voorkom en as ewebeeld van versamelingskompulsies voorgehou word, op net 'n DA-stimulant of gekombineerd met 'n SSRH sal reageer.

Altesaam 165 hertmuise van beide geslagte is aanvanklik vir nesbougedrag ( $7 \times 24$ uur rondtes) ondersoek en daarna albasterbegrawegedrag ( $3 \times 30$ minute rondtes op drie agtereenvolgende dae). Hierna is slegs diere wat GNB- en HAB-gedrag getoon het in die farmakologiese studies gebruik. Vir hierdie spesifieke fase van die studie is diere van elke fenotipe $(n=24$ per gedragsgroep) in vier groepe ( $n=6$ per groep) verdeel en as volg vir 28 dae behandel: groep 1 - essitalopram (50 mg/kg/dag); groep 2 - rasagillien ( $5 \mathrm{mg} / \mathrm{kg} / \mathrm{dag}$ ); groep 3 - 'n kombinasie van esitalopram en rasagillien; en groep 4 - normale drinkwater. Gedragsanalises is na die behandeling herhaal.

Daar is gevind dat HAB sensitief is vir die kombinasie van essitalopram en rasagillien, maar nie vir die enkeltoediening van enige van die geneesmiddels of die kontrole nie. Verder is GNB

Nota: 'n Seleksie van referaatopsommings: Studentesimposium in die Natuurwetenskappe, 25-26 Oktober 2018, SA Akademiegebou, Pretoria, Suid-Afrika. Gasredakteurs: Prof Rudi Pretorius (Departement Geografie, Universiteit van Suid-Afrika); Prof Chris Swanepoel (Departement Besluitkunde, Universiteit van Suid-Afrika); Me Andrea Lombard (Departement Geografie, Universiteit van Suid-Afrika) 
net vir essitalopram sensitief, maar nie vir die kombinasie daarvan met rasagillien nie; rasagillien op sy eie het GNBgedrag vererger. Unieke belonings- en strafgeörienteerde prosesse onderliggend aan hertmuisgedrag word hiermee bevestig en toon dat selektiewe geneesmiddelkeuses op grond hiervan beter behandelingsuitkomste kan hê. 